\title{
Agricultural sector foreign direct investment and economic growth in Ghana

\author{
Dadson Awunyo-Vitor ${ }^{1 *}$ and Ruby Adjoa Sackey ${ }^{2}$
}

\author{
* Correspondence: awunyovitor@ \\ gmail.com; dawunyo-vitor.ksb@ \\ knust.edu.gh \\ ${ }^{1}$ Department of Agricultural \\ Economics, Agribusiness and \\ Extension, Faculty of Agriculture, \\ College of Agriculture and Natural \\ Resources, Kwame Nkrumah \\ University of Science and \\ Technology, Kumasi, Ghana \\ Full list of author information is \\ available at the end of the article
}

\begin{abstract}
The study seeks to establish the relationship between foreign direct investment to Ghana's agriculture sector and economic growth with secondary data mainly sourced from the World Development Indicator. The techniques employed to analyse the data include descriptive statistic, unit root test, Granger causality test and error correction model (ECM). The study accepted a neutrality hypothesis between foreign direct investment to the Ghanaian agricultural sector and its covariates; trade openness, capital and government expenditure. The study also revealed positive and significant relationship between economic growth and foreign direct invest flow to the agricultural sector and volume of trade respectively. However, government expenditure exhibit negative but significant relationship with economic growth. The study contributes to economic development literature from an important but neglected research context with regards to agricultural development via foreign direct investment to support job creation and overall economic development with particular reference to Ghana. Thus, the study recommends that policy should focus on flexible trade policies to attract more foreign direct investment (FDI) inflows to Ghana's agricultural sector to accelerate growth across board.
\end{abstract}

Keywords: Foreign direct investment, Economic growth, Agriculture, Ghana

\section{Introduction}

In 1983, the government launched an economic recovery programme (ERP), which was geared towards resuscitating the economy by taking advantage of the opportunities offered by the new global environment of free trade, ideally utilising FDI. The agricultural sector and sub-sectors made a recovery as a result of this policy after a lower performance, especially in 1983 when performance was at its lowest. The Ghana Investment Promotions Centre (GIPC) and the Divestiture Implementation Committee (DIC) are the two major independent bodies that are responsible for promoting investment activities in the country. These firms attract FDI through capital transfer from non-banking firms to foreign affiliates that had newly established operations in Ghana (Spar and Kou, 1995). According to Ahiakpor (1990), the DIC mostly assumes the form of Joint Ventures with state-owned enterprises (SOE).

The world today is a global economy in which countries continually look for partnerships internationally in order to sustain and keep the economies going. These partnerships include foreign direct investments (FDI), international trade and export among others and are aided by information technology. These international

(c) The Author(s). 2018 Open Access This article is distributed under the terms of the Creative Commons Attribution 4.0 International License (http://creativecommons.org/licenses/by/4.0/), which permits unrestricted use, distribution, and reproduction in any medium, provided you give appropriate credit to the original author(s) and the source, provide a link to the Creative Commons license, and indicate if changes were made. 
partnerships help countries to be innovative and create new and better ways of doing things as well as greater resources to develop, grow and expand their regional economies. It is in the wake of these benefits that Africa opened its borders to foreign investments.

Foreign direct investment has gained much attention in the world with Africa embracing it to boost the performance of their economies through job creation. This late embrace was as a result of scepticism as to its virtues as well as historical and political factors; however, Ghana and other African countries have made strenuous efforts to attract more FDI through institutional and legal frameworks (Ajayi 2006). In spite of this, most of the FDI flows have concentrated in the developed countries, although its importance for developing countries is undeniable. Foreign Direct Investment inflows into developing countries reached its highest level ever ( $\$ 500$ billion $)-a 21 \%$ increase over 2006 (Weissleder 2009).

Despite the fact that about $75 \%$ of the world's poor live in rural areas and are predominantly engaged in agriculture, these sectors have suffered neglect and underinvestment over the last two or more decades with merely $4 \%$ of official development assistance going to agriculture in developing countries (World Bank 2007). In Ghana, the food and agriculture industry plays a major role in the economy as can be seen from 1990 to 1999, where the sector contributed an average of 41.3\% to gross domestic product and $12.2 \%$ of national tax revenue made possible with both local and relatively lower direct investment (Djokoto 2012). Over the years however, agriculture's contribution to gross domestic product has dwindled from 35.4\% in 2006 to $34.3 \%$ in 2007 and to $33.59 \%$ in 2008 recording a slight increase of $34.07 \%$ in 2009 . The growth rate of the sector does not show any clear trend as was the case in 2006 and 2007 with the country recording $4.5 \%$ and $4.3 \%$ respectively. This steady reduction is due to the declining arable land to 'galamsey' as well as the effect of global warming, high production costs, rapid population growth and the resulting need for human settlement and rising urbanisation. In view of this, significant improvements are required to boost agricultural performance and growth in order to increase output through technological innovations and efficiency.

Subsequently, FDI plays a very significant role in increasing growth in the agricultural sector by offsetting the investment and technological gaps, mainly as a result of limited income and sources of credit. According to Krugman and Obstfeld (2009), the most distinctive feature of FDI is that it encompasses the transfer of resources and acquisition of control. The government of Ghana has therefore put measures in place to attract FDI by offering special incentives so that the agricultural sector will benefit from technological spill-over to ensure growth. Such FDI inflows have been shown to play an important role in promoting economic growth, raising a country's technological level and creating new employment in developing countries (Blomström and Kokko 2003; Klein et al. 2003; Borenzstein et al. 1998).

In the light of the above, FDI has been seen as a major stimulus for growth in the agricultural sector through an increase in technology as well as job creation. Out of the 7.1 billion people in the world, 870 million people or one in every eight persons are undernourished and basically hungry; 852 million of these people, representing 15\%, live in developing countries (OECD/FAO 2012). Asia and the Pacific as well as the Caribbean and Latin America have seen a reduction in these numbers due to an 
increase in international trade to its agricultural sectors, while for Africa it has increased over the years. Agriculture, therefore, seems to be the principal driving force for developing countries, especially those without substantial mineral resources. Dependence on agriculture for economic growth is heightened by the proportion of people whose lives depend on the rural economy (FAO 2001a).

The knotty connection between agriculture and livelihoods in the light of attaining the food and agriculture-oriented millennium development goals $\left(\mathrm{MDG}_{\mathrm{s}}\right)$ suggest that any effects of economic policy variables would be important to policy makers. This means that, without policies and mechanisms to mobilise private and public resources on a much larger scale, the internationally agreed $M G_{s}$ cannot be achieved. The role of FDI in agriculture is therefore crucial for economic growth since development in developing countries including Ghana is dependent on agricultural development (World Bank 2007). Thus, it is apt to examine the relationship or the link between FDI to the agricultural sector and economic growth and to know the extent to which one causes the other. The objective of this study is to assess the role of FDI to the Ghanaian agricultural sector. The study seeks to contribute to the growing concerns regarding foreign direct investment flow to emerging economy and its impact on economic development of the country. In addition, it also seeks to contribute to economic development literature from an important but neglected research context with regards to agricultural development via foreign direct investment, which could support job creation and overall economic development with particular reference to Ghana.

\section{Literature review}

There is not a plethora of empirical evidence on the causal relationship between agriculture FDI and economic growth and the ones that do exist are not clear: they do not give a definite causal result. However, for the total economy level, evidence of such relationship abound. The evidence on economic growth effect of FDI is mixed. In its annual report, UNCTAD (1999) fails to identify the direct effect of FDI on economic growth despite the various estimates that are presented (many of which are specified in an ad-hoc manner). The empirical evidence analysed from both the cross-country and time series context by Borenzstein et al. (1998) revealed a strong positive effect of FDI on domestic capital formation while other cross-country studies reject the proposition that FDI does, indeed it pushes out domestic investors. For the time series study, Lipsey (2000, p.74) 'warns' not to expect too much from the time series effects on growth. From his regressions, past FDI inflows do not show a significant positive influence on the current period's investment ratio.

According to neo-classical theory, FDI influences income growth by increasing the amount of capital per person. It spurs long-run growth through such variables as research and development (R\&D) and human capital and this is done through technology transfer to their affiliates and technological spill-overs to unaffiliated firms in the host economy. In the endogenous growth model, FDI increases economic growth by generating technological diffusion from the developed world to the host country (Borenzstein et al. 1998). That is when the level of education in the host country and a measure of its absorptive capacity is high. Balasubramanyam et al. (1996) and De Mello (1999) similarly describes FDI as a composite bundle of capital stock, know-how and technology, that can augment the existing stock of knowledge in the recipient economy 
through labour training, skill acquisition and diffusion, and the introduction of alternative management practices and organisational arrangement. Multinational Companies can speed up the development of new intermediate product varieties, raise product quality, facilitate international collaboration on $R \& D$ and introduce new forms of human capital (Ikara 2003). Empirical studies suggest that FDI is very important because it provides a source of capital and complements domestic private investment. Many studies (e.g. Blomström and Kokko 2003; Chen and Démurger 2002; FAO 2001b) conclude that FDI contributes to total factor productivity and income growth in host economies over and above what domestic investment would trigger. These studies further find that policies that promote indigenous technological capability, such as education, technical training and $R \& D$, increase the aggregate rate of technology transfer from FDI and that export-promoting trade regimes are similarly important prerequisites for positive FDI impact. FDI encourages the adoption of new and improved technology in the production process through capital spill-overs and stimulate knowledge transfers, both in terms of manpower training and skills acquisition and by the introduction of alternative management practices and better organisational arrangements (Grossman 1991; Lensik and Morrissey 2001).

Tian et al. (2004) investigated FDI inflows to regions of China. They noted that regions with higher FDI inflows experienced faster GDP per capita growth. This, they explained, was possible through technology updating. In a firm level study on India, Sarkar and Lai (2009) showed that foreign investment in a firm significantly and positively increased the firm's output. In contrast to this finding, the firms with no foreign investment (FI) were found to be less productive than sectors with more foreign investment compared to those firms in sectors with relatively smaller foreign presence (Djokoto 2013).

Chowdhury and Mavrotas (2006) studied three developing countries, namely Chile, Thailand and Malaysia, who are major recipients of FDI with different macroeconomic indicators and noted that FDI had potential features to which the quality of growth can be affected and with significant implications for poverty reduction. Thus, both industrialised and developing countries have by far offered incentives to attract FDI into their economies because it generates revenue that enhances development and helps protect the poor and vulnerable in the society (Klein et al. 2001). According to Enderwick (2005), the critical inputs to development, particularly in increased knowledge content, growing mobility factors and strong competitive pressure to attract FDI as well as a widespread liberalisation, all have an impact on the way development processes happen. Even though FDI may have a positive impact on the economic growth in developing countries, it depends largely on other important factors such as the human capital base in the host country, the trade regime and the degree of openness in the economy. The host developing country is basically required to carefully consider investment in appropriate assets and infrastructure (human capital), as well as the coordinated integration of a range of policies as they are important in attracting FDI.

Msuya (2007), in a specific study of the impact of agricultural FDI to Tanzania, concluded that agriculture has a much more far-reaching economic and social impact than in other sectors. Zhang (2001) in his study of 11 countries of Latin America and East Asia finds a strong granger-causal relationship between FDI and economic growth, although the impact on host economic growth may depend on particular host country 
characteristics. Basu et al. (2003) conclude that a long-run relationship exists between FDI and GDP using a panel cointegration framework for a panel of 23 developing countries. The cointegrating vectors revealed a bi-directional causality between GDP and growth for more open economies.

In another study, Hansen and Rand (2005) analyse the granger causality between FDI and GDP among 31 developing countries that were sampled and determines bi-directional causality between FDI/GDP ratio and the level of GDP. They further assert that GDP does not have any long-run impact on FDI while FDI has a lasting impact on the level of GDP, and so FDI causes growth. Choe (2003), however, used the panel VAR model to show the causal relationship between economic growth and FDI for 80 countries over the period 1971-1995. The results, like the others, show that FDI granger causes economic growth and vice versa. The effects may, however, be more apparent from growth to FDI than from FDI to growth, suggesting that a strong positive association exists between economic growth and FDI inflows.

Chowdhury and Mavrotas (2006) took an entirely different dimension altogether as they tested for Granger causality using the Toda and Yamamoto (1995) specification; hence, overcoming the possible pre-testing problems in relation to tests for cointegration between series. They find that FDI did not "Granger-cause" GDP in Chile, but that there is a bi-directional causality between GDP and FDI in Malaysia and Thailand. Meanwhile, there seemed to be a strong relationship between FDI and growth but apparently this relationship is seemingly high across heterogeneous countries: the empirical studies however generally agreed that FDI, on average, has an impact on growth in the Granger-causal sense.

Karikari (1992) concludes that, within the period 1961 to 1988, FDI did not Granger-cause economic output in Ghana, and that it was the other way around; economic output Granger-caused FDI. Gyapong and Karikari (1999) examined causal relationships between FDI and economic performance in two Sub-Saharan African countries (Ghana and Ivory Coast) from 1960 to 1980 and concluded that economic performance is influenced positively by FDI, especially in an inward-oriented economy. Asafu-Adjaye (2005) found a statistically positive correlation between FDI and economic growth within the period 1973 to 2003 using the granger-causality tests to establish that there is a bilateral effect between the two variables. The paper described the movements of agricultural growth and FDI to agriculture, and determined the causality between the two variables. Agricultural growth was represented by real agricultural GDP growth rate and FDI represented by a ratio of inward FDIs to agriculture as a ratio of agriculture value added. Frimpong and Oteng-Abayie (2008) used data covering 1970 to 2002 and concluded that, indeed, there was no Granger causality between economic growth and output; however, after breaking the sample into 1970-1983 and 1984-2002, the former sample results concurred with no causality conclusion of Karikari (1992). Thus, the latter sample showed a contrary outcome given a relatively stable political and economic environment in that FDI Granger-caused GDP growth positively. In another agriculture-specific study, Djokoto (2012) found that, in the short run, the coefficient for FDI inflows and imports were statistically significant. The coefficients between exports and FDI, although negative, were not statistically significant. In the long run, there was a feedback between imports and FDI. 
Empirical studies on other variables of economic growth (GDP growth) and agricultural FDI have varying results. Chaudhry et al. (2013) analysis spans from 1972 to 2007 and investigates the relationship between trade liberalisation, human capital and economic growth in Pakistan. By applying cointegration and granger causality techniques to time series, the empirical result revealed that there exists both short-run and long-run cointegration and causality relationships among variables in the growth model. In Frankel and Romer's (1996) work, the empirical investigation stated that countries' geographic characteristics have important effects on its trade. They used the geographical components of countries' trade to obtain instrumental variable components and the result suggests that ordinary least squares estimates understate the effects of trade and that trade has a robust positive effect on income. Knoop (1999), in a time series analysis of the USA using an endogenous growth model, concludes that reducing the size of the government actually reduces growth. He indicates that government purchases directly affect aggregate productivity and utility, and that macroeconomic effects of changes in fiscal policy are less sensitive to the mix of spending cuts as they are to the mix of tax cuts. There is very little empirical evidence on population and economic growth; however, Becker et al. (1999, p. 149) analyse the positive as well as the negative effects of population on productivity. According to them, population may reduce productivity as a result of traditional diminishing returns from more intensive use of land and other natural resources while larger populations, on the other hand, encourage greater specialisation and increased investments. So, the net relation between greater population and per capita income depends on whether the inducements to human capital and expansion of knowledge are stronger than diminishing returns to natural resources.

Awokuse (2007) examines the causality between exports, imports and economic growth in three transition economies-Bulgaria, Czech Republic and Poland-all at country level. The results show bi-directional causality between exports and growth in Bulgaria, but that of the Czech Republic shows unilateral causality from export and import on growth; and for Poland, only the import-led hypothesis can be supported. Djokoto (2013) examines the relationship between openness and agricultural performance and concluded that there was no long-run relationship between FDI and trade openness on the one hand, and agricultural performance on the other hand. However, in the short run, trade openness and FDI exerted a statistically significant negative effect on agricultural performance. This result provides an incentive for the re-examination of the type of FDI attracted into the sector.

The empirical evidence regarding the effect of government spending on economic growth is mixed. Saunders (1985) uses data from OECD countries to test the effect of government expenditure on the economy and his results shows a negative relation between average economic growth and average share of total government expenditure in GDP. Ghura (1995) uses pooled time series and cross-section data for 33 sub-Saharan African countries from the period 1970-1990 and the evidence shows the existence of a negative relationship between government consumption and economic growth. His study likewise revealed the fact that countries that have higher growth experience higher investment ratios as well as higher exports. Ianchovichina and Kacker (2005) studied 55 developing countries, representing major world regions and which account for close to $80 \%$ of the developing world's GDP. The authors find that, 
for the average developing country, the largest growth dividend comes from continued improvement in public infrastructure, then the growth of contributions of rising senior high school enrolment, trade openness and financial deepening. They forecast that the four growth determinants stated above differ from country to country both quantitatively and qualitatively; and that their contribution to average, annual per capita GDP growth is only $1 \%$ and so failure to keep improving public infrastructure alone could reduce growth by $50 \%$.

\section{Methods}

This study employed secondary data sourced from the world development indicators, Bank of Ghana statistical bulletins and Ghana Investment Promotion Centre (GIPC). The data span from 1975 to 2017. The techniques employed to analyse the data include descriptive statistic, the unit root test, Granger Causality test and error correction model (ECM). The presence of unit root in time series data may lead to spurious regression. To avoid this, a test for the unit root was undertaken. The Augmented Dickey Fuller unit root test was employed to test whether the data series variable is stationary or non-stationary. The test employed the existence of the unit root as the null hypothesis while the non-existence of the unit root in the data series is the alternative hypothesis. The Phillips-Perron test was used as a triangulation measure due to some limitations of the Augmented Dickey Fuller unit root test. An advantage of the Philips-Perron test is non-parametric to the $t$ test statistic, which does not require selecting the level of serial correlation as required in the Augmented Dickey-Fuller (ADF) test for unit root. This test, however, employs the same estimation scheme as in the Dickey-Fuller test (DF), but corrects the statistic to conduct for auto-correlations and heteroskedasticity. The ADF test is specified as follows:

$$
\Delta Y_{t}=\beta_{o}+\beta_{1} Y_{t-1}+\beta_{2} Y_{t-2}+\beta_{3} Y_{t-2}+\ldots \ldots+\beta_{p} Y_{t-p}+\varepsilon_{t}
$$

where $Y_{t}$ represents time series data on GDP growth to be tested, $\beta_{0}$ is the intercept term, $\beta_{1}$ is the coefficient of interest in the unit root test, $\beta_{2}, \beta_{3} \ldots \beta_{p}$ are the parameters of the augmented lagged difference of $Y_{t}$ to represent the $p^{\text {th }}$-order auto-regressive process, and $\varepsilon_{t}$ is the error term. In carrying out the unit root test, the study seeks to test the hypothesis that:

$$
H_{o}: \beta=0 \text {, Non-stationary (there is unit root) }
$$

$H_{1}: \beta \neq 0$, Stationary (no unit root)

To test the null hypothesis, the $t$ statistic is calculated and compared to the critical values to make a decision. If the test statistic is greater than the critical values, the null hypothesis of an implied non-stationary series is rejected. If the null hypothesis is rejected, then the time series data is stationary, hence no unit root. Based on the results of the above test, where we observed a non-stationary series, the Johansen cointegration test procedure was used to establish the existence of a long-run relationship among the variables. The equation for the Johansen Cointegration test is specified as:

$$
Y_{t}=\mu+\beta_{1} y_{t-1}+\ldots \ldots \ldots \ldots+\beta_{p} y_{t-p}+\varepsilon_{t}
$$

where $Y_{t}$ is an $n x 1$ vector of variables that are integrated of order one and is usually denoted as $I(1)$ and $\varepsilon_{t}$ is an $n x 1$ vector. In addition, a bi-variate granger causality test was used to examine the causal link between the variables, gross domestic product 
(GDP) and foreign direct investment in agriculture (FDIA), using Eqs. 3 and 4 as specified below.

$$
\begin{aligned}
& \Delta \ln G D P_{t}=\alpha_{0}+\sum_{k=1}^{m} \alpha_{1 i} \Delta \ln G D P_{t-k}+\sum_{k=1}^{n} \alpha_{2 i} \Delta \ln F D I A_{t-k}+\alpha_{3} \gamma_{t-1}+\varepsilon_{t} \\
& \Delta \ln F D I A_{t}=\phi_{0}+\sum_{k=1}^{m} \phi_{1 i} \Delta \ln F D I A_{A t-k}+\sum_{k=1}^{n} \phi_{2 i} \Delta \ln G D P_{t-k}+\phi_{3} \gamma_{t-1}+\mu_{t}
\end{aligned}
$$

In the equation above, $\alpha_{0}$ and $\phi_{0}$ are the intercepts and $\alpha_{i}$ and $\phi_{i}$ are the coefficients of the lagged dependent variables and the parameters of the independent variables, whereas $\Delta$ is the difference operator. The error terms are $\varepsilon_{t}$ and $\mu_{t}$, and are assumed to be uncorrelated, $k$ is the lag length and $\gamma_{t-1}$ is the speed of adjustment and measures the rate of adjustment to long-run equilibrium in case there is a shock to the system. All the other variables and parameters are as defined earlier.

Finally, error correction model was used to evaluate the relationship between variables. The model for the ECM is specified as follows:

$$
\begin{aligned}
\Delta \ln G D P_{t}=\delta_{0} & +\delta_{1} \sum_{i=1}^{n} \Delta \ln G D P_{t-i}+\delta_{2} \sum_{i=1}^{n} \Delta \ln F D I A_{t-i}+\delta_{3} \sum_{i=1}^{n} \Delta \ln K_{t-i} \\
& +\delta_{4} \sum_{i=1}^{n} \Delta \ln G E_{t-i}+\delta_{5} \sum_{i=1}^{n} \Delta \ln T O P_{t-i}+\delta_{6} E C M_{t-1}+\varepsilon_{t}
\end{aligned}
$$

The variables are as defined above and the coefficient $\delta_{6}$ measures the deviation from the long-run equilibrium period. The study adopted the approach used by Ohen et al. (2007) to obtain a parsimonious dynamic ECM by first estimating an overparameterized model and then gradually eliminating lags that were insignificant until a parsimonious and more interpretable model was obtained.

\section{Results and discussion}

\section{Descriptive statistics}

Ahead of the time series econometric analysis, a detailed analysis was carried out to determine the trend movements of the variables. The complete data set consists of 38 years of annual observations from 1975 to 2017 on the selected variables.

The descriptive statistics in Table 1 describe the basic features of the data in the study and enable comparisons. The average gross domestic product for the study period is C18.567 million Ghana Cedis with standard deviation of 0.482 . The average for FDI agriculture is 751.742 while the standard deviation is 1824.94 and that of general FDI is 4.6 with an average of 2.441. On average, the government expenditure index is 3.0 and that for trade is 3.856 with a standard deviation of 0.677 and 0.729 respectively. The average for capital is 2.685 with a standard deviation of 0.623 .

Table 1 Descriptive statistics of variables

\begin{tabular}{lllll}
\hline Variable & Mean & Standard deviation & Minimum & Maximum \\
\hline InGDP & 18.567 & 0.482 & 17.951 & 19.6 \\
InFDIG & 2.441 & 4.6228 & -0.00008 & 15.836 \\
InFDIA & 751.742 & 1824.94 & -0.002 & 7589.94 \\
InGE & 3.008 & 0.677 & 1.2055 & 3.888 \\
InK & 2.685 & 0.623 & 1.2172 & 3.495 \\
InTOP & 3.856 & 0.729 & 1.8438 & 4.754 \\
\hline
\end{tabular}


The minimum and maximum values identify a possible outlier. In the 38-year period, GDP's minimum value was 17.951 and the maximum value 19.6 while agricultural FDI had the smallest minimum and largest maximum values of -0.002 and 7589.94 respectively: a call to investigate the cause of the extreme values. Those of government expenditure and capital are 1.2055 and 1.2172 for the minimum values respectively and 3.888 as well as 3.495 for the respective maximum values. The gross FDI in general has extreme values similar to agricultural FDI; however, trade had normal values.

From the econometric methodology, the variables were tested for the presence of a unit root using the Augmented Dickey-Fuller (ADF) and Philips-Perron (PP) tests. The Philips-Perron test was used to augment the ADF test since it has the ability to correct for serial correlation and heteroskedastic error terms. The null hypothesis for these tests is that there is a presence of a non-stationary series against the alternative hypothesis of a stationary series.

The unit root test is important because the non-stationary series regression analysis leads to spurious regression with ordinary least squares (OLS) estimations with the wrong magnitude and signs of the parameter of the regressors and, consequently, wrong inferred implications. The test results are presented in Table 2.

Based on the test results, the null hypothesis that states that the variables in the series are non-stationary is accepted in favour of the alternative of stationarity of the variables in the data series. However, all the data series became stationary after first differencing. Specifically, the log of gross domestic product (GDP) and total foreign direct investment (FDIG) became stationary after first differencing at 5\% significance level. Foreign direct investment to the agriculture sector (FDIA), government consumption expenditure, trade openness and gross capital formation became stationary after first differencing at $10 \%$ significance level using both ADF and PP unit root tests. Since all the variables were stationary at first differencing, Johansen cointegrating was used to estimate the effect of the regressors on the dependent variable since it is designed for strictly I (1) data series. In the preceding section, presence of the unit root was established, hence cointegration analysis was undertaken and the results are presented below.

Table 2 Unit root test results

\begin{tabular}{|c|c|c|c|c|}
\hline \multirow[t]{2}{*}{ Variables $^{a}$} & \multicolumn{2}{|l|}{ ADF } & \multicolumn{2}{|l|}{ PPP } \\
\hline & Level & First difference & Level & First difference \\
\hline Gross domestic product (GDP) & 4.129 & $-3.616^{* *}$ & 3.523 & $-3.658^{* *}$ \\
\hline Foreign direct investment-Agric (FDIA) & 4.059 & $-4.553^{* * *}$ & 5.980 & $-4.899^{* * *}$ \\
\hline Foreign direct investment-gross (FDIG) & 2.556 & $-3.454^{* *}$ & 2.220 & $-3.352^{* *}$ \\
\hline Government expenditure & -0.841 & $-4.281^{* * *}$ & -1.120 & $-4.154^{* * *}$ \\
\hline Capital stock & -1.096 & $-6.580^{* * *}$ & -1.059 & $-6.638^{* * *}$ \\
\hline Trade openness & -0.850 & $-4.101^{* * *}$ & -1.075 & $-3.937^{* * *}$ \\
\hline
\end{tabular}

Critical values were $-3.662,-2.964$ and -2.616 for 1,5 , and $10 \%$ level of significance. Symbols ${ }^{* *}$ and ${ }^{* *}$ denotes $1 \%$ and $5 \%$ levels of significance respectively

a All values are in natural log 


\section{Results of the cointegration test}

In cointegration, the property of both time series data share common stochastic trends; that is, the change in average value in random or processes integrated of order I (1). Since the presence of a unit root was established, the study used the Johansen cointegration approach to establish the relationship between two variables, particularly as all the variables were non-stationary after first difference. The results of the cointegration test are presented in Tables 3 and 4 respectively.

For the first value, the trace statistic value of 92.078 is greater than the critical value of 68.52 and so the null hypothesis of no cointegration is rejected, which means that there is at least one cointegrating relationship. The second value has the trace statistic of 51.490 being greater than the critical value of 47.21,meaning the null hypothesis of cointegration is rejected once again and that there is at least two cointegrating relationships. Since all subsequent values have lesser trace statistics than critical values, it can be said that there is at least two cointegrating relationships counting from the first value. Similarly, the maximum eigenvalue statistics display the same level of cointegrating rank. Thus, the maximum eigen statistics shows that there exist at least two cointegrating equations among the data set, since there exists a cointegrating relationship among the data series,

Table 4 presents the results of the test for cointegration among the data series. However, total foreign direct investment was used to replace FDI in agriculture in this scenario. The trace statistics shows the existence of three cointegrating equations and, on the other hand, the maximum eigen values shows the existence of no cointegrating equations. The study therefore is based on the trace statistics to estimate a long-run relationship among the data series using a bivariate Granger causality test.

\section{Results of the Granger causality test}

The Granger causality test results, presented in Table 5, shows that economic growth does not cause foreign direct investment in agriculture nor does foreign direct investment granger cause economic growth. The result confirms the neutrality concept of no granger causality.

With regards to causality between foreign direct investment in agriculture and government expenditure, the results reveal that FDI in agriculture does not cause economic growth nor does economic growth cause FDl in agriculture. This result correspondingly confirms the neutrality concept of no granger causality. Similarly, there exist no direction of causation between foreign direct investments in agriculture and

Table 3 Cointegration test results (with FDIA)

\begin{tabular}{llllll}
\hline$H_{0}$ & $H_{1}$ & Trace statistics & $95 \%$ Critical value (trace) & Max statistic & 95\% Critical value (max) \\
\hline$r=0$ & $r \geq 1$ & 92.078 & 68.52 & 40.589 & 33.46 \\
$r \leq 1$ & $r \geq 2$ & 51.490 & 47.21 & 28.793 & 27.07 \\
$r \leq 2$ & $r \geq 3$ & 22.696 & 29.68 & 15.263 & 20.97 \\
$r \leq 3$ & $r \geq 4$ & 7.433 & 15.41 & 7.251 & 14.07 \\
$r \leq 4$ & $r \geq 5$ & 0.182 & 3.76 & 0.182 & 3.76 \\
\hline
\end{tabular}

Both the trace and max-eigenvalue tests indicate at least two cointegrating equations 
Table 4 Cointegration test results (with FDIG)

\begin{tabular}{llllll}
\hline$H_{0}$ & $H_{1}$ & Trace statistics & $95 \%$ Critical value (trace) & Max statistic & $95 \%$ Critical value (max) \\
\hline$r=0$ & $r \geq 1$ & 94.016 & 68.52 & 33.459 & 33.46 \\
$r \leq 1$ & $r \geq 2$ & 60.556 & 47.21 & 28.286 & 27.07 \\
$r \leq 2$ & $r \geq 3$ & 32.271 & 29.68 & 20.574 & 20.97 \\
$r \leq 3$ & $r \geq 4$ & 11.696 & 15.41 & 11.489 & 14.07 \\
$r \leq 4$ & $r \geq 5$ & 0207 & 3.76 & 0.207 & 3.76 \\
\hline
\end{tabular}

capital, and evidence of the granger neutrality concept between trade openness and foreign direct investment in agriculture.

The study likewise examined the direction of causation between gross foreign direct investment on the one hand, and economic growth, government expenditure, capital and trade openness on the other hand respectively. Based on the results, the study failed to accept the null hypothesis of no granger causality between GDP and gross foreign direct investment. The study shows no causality between gross foreign direct investment on the one hand and capital, government expenditure and trade openness on the other hand respectively. In other words, the result confirms the neutrality concept between gross foreign direct investment and capital, government expenditure and trade openness.

The effect of agricultural sector foreign direct investment on economic growth

Table 6 shows the results of estimated ECM model (Eq. 5).The $R^{2}$ of the model is 0.789 , which means that the specified explanatory variables explained about $78 \%$ of the variation in GDP. The $F$ statistics of 148.7 is significant at $1 \%$, which implies that the equation has a goodness of fit.

Table 5 Bivariate Granger causality test results

\begin{tabular}{lll}
\hline Null hypothesis & F statistics & $P$ value \\
\hline InGDP does not Granger cause FDIA & 3.747 & 0.061 \\
FDIA does not Granger cause InGDP & 0.090 & 0.766 \\
InGE does not Granger cause FDIA & 0.170 & 0.683 \\
FDIA does not Granger cause InGE & 0.545 & 0.465 \\
InK does not Granger cause FDIA & 0.657 & 0.423 \\
FDIAdoes not Granger cause InK & 0.090 & 0.767 \\
InTOP does not Granger cause FDIA & 0.369 & 0.547 \\
FDIA does not Granger cause InTOP & 0.151 & 0.700 \\
InGDP does not Granger cause FDIG & 5.185 & 0.029 \\
FDIG does not Granger cause InGDP & 0.019 & 0.890 \\
InGE does not Granger cause FDIG & 0.170 & 0.683 \\
FDIG does not Granger cause InGE & 0.976 & 0.330 \\
InK does not Granger cause FDIG & 0.746 & 0.394 \\
FDIG does not Granger cause InK & 0.262 & 0.612 \\
InTOP does not Granger cause FDIG & 0.424 & 0.519 \\
FDIG does not Granger cause InTOP & 0.262 & 0.612 \\
\hline
\end{tabular}


Table 6 Results of the ECM model

\begin{tabular}{llll}
\hline Variables & Coefficients & Standard error & $t$ values \\
\hline$\Delta n G D P_{t-1}$ & 0.16272 & 0.09961 & 1.634 \\
$\triangle n F D I A$ & $0.014^{* * *}$ & 0.0017 & 8.235 \\
$\Delta n K$ & -2.102 & 1.9845 & -1.059 \\
$\Delta n G E$ & $-0.678^{* *}$ & 0.282 & -2.404 \\
$\Delta n T O P$ & $0.579^{*}$ & 0.293 & 1.946 \\
$E C M$ & $-0.6654^{* * *}$ & 0.1245 & -5.345 \\
Constant & 20.132 & 30.452 & 0.661 \\
$R^{2}$ & 0.789 & & \\
F-cal & $148.7^{* * *}$ & & \\
DW & 1.985 & & \\
Normality test & $42.398^{* * *}$ & & \\
RESET test & $0.0751(0.7821)$ & & \\
\hline
\end{tabular}

The value in bracket represents $t$ values. The asterisks ${ }^{*},{ }^{*}$ and ${ }^{* * *}$ represents 10,5 , and $1 \%$ significance level respectively

The results show mixed findings in terms of the sign of the parameters as well as the statistical significance of the variables. From Table 6, a significant positive relationship is evident between foreign direct investment that goes into agriculture (FDIA) and economic growth. Thus, changes in economic growth and FDI in agriculture move in the same direction. The result validates the long-run relationship between foreign direct investment flow into agriculture and economic growth in Ghana. The coefficient of FDI flow into agriculture is 0.026 , which is statistically significant at $1 \%$ level. This means that a unit change in FDI flow in to the agricultural sector in Ghana will lead to about $2.6 \%$ unit change in economic growth in the same direction.

The result likewise shows a statistically significant effect of government consumption expenditure on economic growth. However, the direction of the relationship between government expenditure and economic growth is negative. This result might be due to the fact that the major part of government expenditure in Ghana are salaries paid to public sector workers, with anecdotal evidence suggesting that it stands at about $60 \%$ of the government budget. The coefficient of the government expenditure variable is -0.678 , which mean a change in government expenditure would reduce the change in GDP by about $67 \%$.Similarly, the results show a positive significant relationship between economic growth and trade openness. The coefficient of this variable is 0.579 and it is significant at $10 \%$ level of significance. The coefficient of the error correction term is negative $(-0.6654)$ and it is statistically significant at $1 \%$ level of significance. This indicates that any deviation from the long-run equilibrium between variables is corrected by about $66 \%$ for each period and suggests a fairly high speed of convergence to equilibrium.

\section{Conclusions}

We provide a longitudinal study of the causal link between agricultural sector foreign direct investment and economic growth in Ghana by critically and analytically evaluating the role that foreign direct investment inflow to the agricultural sector played in economic growth from 1975 to 2017. The study attempted to verify whether 
FDI inflows to the agriculture sector affect economic growth and, furthermore, the direction of causation between economic growth and FDI to agriculture.

The result of the study revealed that FDI inflows into the agricultural sector have a positive effect on Ghana's economy. In other words, a positive inflow of FDI into the agricultural sector will lead to a positive change in economic growth. Based on the result of the granger causality test, it can be concluded that policies that influence economic growth will indirectly influence the level of FDI flows into the agricultural sector.

The presence of a causal effect of trade on economic growth has implications of great consequence on development strategies for Ghana, a developing country. The findings provide evidence to support trade in the export theory. Thus, trade is important in fuelling economic growth.

An essential implication of the result is that FDI to the agricultural sector has a significant effect on economic growth. It is recommended that policies and incentives to foreign investment and institutional set-up of farmers should be encouraged to play an important role in promoting investment to the sector. It is important that government policies concentrate on FDI inflows to the agricultural sector since it accelerates growth across the board. To this end, there should be well-defined policy that would encourage the provision of infrastructure to support investors that are ready to invest funds into the agricultural sector and the economy at large.

Since trade openness causes economic growth, the achievement of a certain degree of development may be a pre-requisite for the country to expand and make its trade policies more flexible. In addition, there is the need to improve the country's attractiveness to multinationals operating in the agricultural sector for inflow of foreign direct investment to the agricultural sector. Since economic growth does not depend solely on macroeconomic indicators or political stability, the Ghana Investment Promotion Centre must be encouraged to develop policies that would attract more foreign direct investment into the agricultural sector to improve economic growth.

Availability of data and materials

The datasets generated and/or analysed during the current study are available in the [World Bank and Bank of Ghana] repository, [https://data.worldbank.org/products/wdi and https://www.bog.gov.gh/statistics/ statistical-bulletin respectively].

Authors' contributions

This work was carried out in collaboration with all authors. DAV designed the study, performed the statistical analysis, and wrote the first draft of the manuscript. RAS managed the data collection and the literature searches. All authors read and approved the final manuscript.

Competing interests

The authors declare that they have no competing interests.

\section{Publisher's Note}

Springer Nature remains neutral with regard to jurisdictional claims in published maps and institutional affiliations.

Author details

${ }^{1}$ Department of Agricultural Economics, Agribusiness and Extension, Faculty of Agriculture, College of Agriculture and Natural Resources, Kwame Nkrumah University of Science and Technology, Kumasi, Ghana. ${ }^{2}$ Department of Accounting Studies Education, College of Technology Education, University of Education, Winneba, Kumasi, Ghana. 
Received: 6 March 2018 Accepted: 26 September 2018

Published online: 15 November 2018

\section{References}

Ahiakpor, J. C. W. (1990). Multinationals and economic development: an integration of competing theories. London: Routledge.

Ajayi, S. I. (2006). The determinants of foreign direct Investment in Africa: A survey of the evidence. In S. I. Ajayi (Ed.), Foreign direct Investment in sub-Saharan Africa: Origins, targets and potential. Nairobi: AERC.

Asafu-Adjaye, J. (2005). What has been the impact of foreign direct investment in Ghana? IEA Policy Analysis, 1(9), 1-5.

Awokuse, T. O. (2007). Causality between exports, imports, and economic growth: evidence from transition economies. Economics Letters, 94(3), 389-395.

Balasubramanyam, V. N., Salisu, M., \& Sapsford, D. (1996). Foreign direct investment and growth in EP and IS countries. Economic Journal, 106(434), 92-105.

Basu, P., Chakraborty, C., \& Reagle, D. (2003). Liberalization, FDI, and growth in developing countries: a panel cointegration approach. Economic Inquiry, 41(3), 510-516.

Becker, G. S., Glaeser, E. L., \& Murphy, K. M. (1999). Population and economic growth. American Economic Review, 89(2), $145-149$.

Blomström, M., \& Kokko, A. (2003).The economics of foreign direct investment incentives ElJS working paper 168 Stockholm School of Economics, The European Institute of Japanese Studies. Retrieved from: http://www.hhs. se/eijs

Borenzstein, E., De Gregorio, J., \& Lee, W. J. (1998). How does foreign direct investment affect economic growth? Journal of International Economics, 45, 115-135.

Chaudhry, I. N., Asif, M., \& Mian, S. M. (2013). Empirical relationship between foreign direct investment and economic growth: an ARDL co-integratio $n$ approach for China. China Finance Review International, 3(1), 26-41 https://doi.org/10.1108/20441391311290767.

Chen, Y., \& Démurger, S. (2002). Foreign direct investment and manufacturing productivity in China. Paper presented at the Annual Conference of the Chinese Economic Association (UK) in London on March 25-26, 2002. UK.

Choe, J. I. (2003). Do foreign direct investment and gross domestic investment promote economic growth? Review of Development Economics, 7(1), 44-57.

Chowdhury, A., \& Mavrotas, G. (2006). FDI and growth: What causes what? The World Economy, 29(1), 9-19.

Djokoto, G. J. (2012). Does causal relationships exist between external trade and foreign direct investment flow to agriculture in Ghana? International Journal of Business and Management, 7(2), 179-193 https://doi.org/10.5539/ ijbm.v7n2p179.

Djokoto, G. J. (2013). Openness and agricultural performance in Ghana. Journal of Science and Technology, 33(2), 24-36.

Enderwick, P. (2005). Attracting desirable FDI: theory and evidence. Transnational Corporations, 14(2), 94-119.

FAO. (2001a). The state of food and agriculture, 2001. Rome.

FAO. (2001b). Agricultural investment and productivity in developing countries, economic and social development paper 148. Retrieved from www.fao.org.

Frankel, J.A., and Romer, D. Trade and growth: an empirical investigation. National Bureau of economic research (NBER), Working Paper No. 5476. Massachusetts: National Bureau of economic research, 1996.

Frimpong, J. M., \& Oteng-Abayie, E. F. (2008). Bivariate causality analysis between FDI inflows and economic growth in Ghana. International Research Journal of Finance and Economics, 15(5), 95-104.

Ghura, D. (1995). Macro policies, external forces, and economic growth in sub-Saharan Africa. Economic Development and Cultural Change, 43(4), 759-778.

Grossman H. (1991) A General Equilibrium Model of Insurrections. American Economic Review, 81(4), 912-921.

Gyapong, O. A., \& Karikari, A. J. (1999). Direct foreign investment strategies and economic performance in Ghana and Ivory Coast. Journal of Economic Development., 24(6), 133-147.

Hansen, H., \& Rand, J. (2005). On the causal links between FDI and growth in developing countries. UNU-WIDER research paper no. 2005/31, Helsinki. In Finland.

lanchovichina, E., \& Kacker, P. (2005). "Growth trends in the developing world: country forecasts and determinants," policy research working paper series 3775. Washington D.C.: The World Bank.

Ikara, M. (2003). Foreign direct investment (FDI), technology transfer, and poverty alleviation: Africa's hopes and dilemma. ATPS Special Paper Series No. 16. Nairobi, Kenya: ATPS Communications Department.

Karikari, J. A. (1992). Causality between direct foreign investment and economic output in Ghana. Journal of Economic Development, 17(1), 7-17.

Klein, M., Aaron, C., \& Hadjimichael, B. (2001). Foreign direct investment and poverty reduction. Paper presented at the OECD conference on new horizons and policy challenges for foreign direct investment in the 21st century, 26-27 November. Mexico City.

Klein, M., Aaron, C., \& Hadjimichael, B. (2003). Foreign direct investment and poverty reduction. World Bank, Retrieved from http://lcgbangladesh.org.

Knoop, T. A. (1999). Growth, welfare, and the size of government. Journal of Economic Inquiry, 37(1), 103-119.

Krugman, P., \& Obstfeld, M. (2009). International economics theory \& policy (8th ed.). USA: Pearson Addison Wesley.

Lensik, R., \& Morrissey, O. (2001). "Foreign direct investment: flows, volatility and growth". Paper presented at the development economics study group conference. UK: University of Nottingham.

Lipsey, R. E. (2000). Inward FDI and economic growth in developing countries. Transnational Corporations, 9(1), 67-95.

De Mello L.R. (1999). Foreign direct investment led growth: evidence from time series and panel data, Oxford Economic Papers, 51, 133-151. https://doi.org/10.1093/oep/51.1.133

Msuya, E. (2007). "The Impact of Foreign Direct Investment on agricultural productivity and poverty reduction in Tanzania," MPRA paper 3671. Germany: University Library of Munich.

OECD/FAO. (2012). OECD-FAO agricultural outlook 2010. Paris: OECD Publishing.

Ohen, S. B., Abang, S. O., \& Idiong, I. C. (2007). Price transmission and market integration: vertical and horizontal price linkages for live catfish in Nigeria. Journal of Agriculture \& Social Sciences, 3(1), 17-20. 
Sarkar, S., \& Lai, Y. C. (2009). Foreign direct investment, spillovers and output dispersion-the case in India. International Journal of Information and Management Science, 20(4), 491-503.

Saunders, P. (1985). Public expenditure and economic performance in OECD countries. Journal of Public Policy, 5(1), 1-21.

Spar, D.L., and Kou, J., (1995). Note of foreign direct investment. Harvard Business School Review, 9, 795-037.

Tian, X., Lin, S., \& Lo, I. (2004). Foreign direct investment and economic performance in transition economies: evidence from China. Post-Communist Economies, 16(4), 497-510. https://doi.org/10.1080/1463137042000309584.

Toda, H. Y., \& Yamamoto, T. (1995). Statistical inference in vector autoregressions with possibly integrated processes. Journal of Econometrics, 66(1-2), 225-250.

UNCTAD. (1999). Foreign direct investment in Africa: performance and potential. New York: United Nations.

Weissleder, L. (2009). Foreign direct investment in the agricultural sector in Ethopia. EcoFair Trade Dialogue: discussion paper No. 12. Germany: 2009 University of Born.

World Bank. (2007). World development report 2008: Agriculture for development. Washington, DC.

Zhang, K. H. (2001). Does foreign direct investment promote economic growth? Evidence from East Asia and Latin America. Contemporary Economic Policy, 19(2), 175-185.

Submit your manuscript to a SpringerOpen ${ }^{\circ}$ journal and benefit from:

- Convenient online submission

- Rigorous peer review

- Open access: articles freely available online

- High visibility within the field

- Retaining the copyright to your article

Submit your next manuscript at $\boldsymbol{\nabla}$ springeropen.com 